\title{
THE STRATEGIES USED BY ENGLISH TEACHER TO TEACH VOCABULARY AT GENTA ENGLISH COURSE PARE-KEDIRI
}

\author{
Dewi Saniyah, Imam Baehaki
}

\begin{abstract}
This study was aimed to find out the used of strategies used by English teacher to teach vocabulary. for those who are learning English, it is essential to learn about vocabulary mastery in order they can use it to communicate and to express their ideas, opinions, thoughts by using words, sentences, paragraphs through written form without having face to face with other people directly. The design of this research in qualitative descriptive. This research was conducted in Genta English course. The students were 10 students. It consist of 9 female and 1 male. To know the result of the student activity, the researcher used observation checklist, field note and interview. Teacher strategies in teaching vocabulary is the ways or steps that help learners to learning vocabulary by acting one of the strategies as steps formula, so that strategy become a facility which increasing learners understanding in learning vocabulary. It means use the strategies is good in teaching vocabulary.
\end{abstract}

Keyword: English teacher's strategies, teaching vocabulary

\section{INTRODUCTION}

The student not only can study English at school, but also they learn English in non-formal education. The purpose of non-formal education is to complete, to change, and to add the student's knowledge that they ever or never get from formal education. Moreover, some people who want to get job and best education in the future actually take non-formal education to increase their English ability. Non-formal education is any organized and systematic activity, outside the school system, conducted independently or the important part of the larger activity that is intentionally made to serve the specific student to get the goal of their study. In this era non-formal education that can help the students to get the different teaching and learning process from formal education that they get at the school.

There are four skills that should be mastered by students in learning English. They are speaking, listening, reading, and writing. Besides the four English skills, to support the mastery of the four language skills the students should have well understanding of English component such as vocabulary, pronunciation, and grammar. Vocabulary as one of English component is very important to learn. Before the students master the four skills they have to know 13 some vocabularies to support them in learning English. Richard (2005:5) says that vocabulary is core component of listening, speaking, reading and writing. Vocabulary is very important to be learnt by the students who want to master a language. 
Four main research questions were addressed in this study:

1. How is the preparation of the strategies used by English teacher to teach vocabulary at Genta English course?
a. Curriculum
b. Syllabus
c. Lesson plan
d. Method
e. Media

2. How is the implementation of the strategies used by English teacher to teach vocabulary at Genta English course Pare-Kediri in the terms of :
a. Pre- Teaching
b. Whilst Teaching
c. Post- Teaching

3. How is the students' response after learning vocabulary?

4. How is the evaluation of strategies used by English teacher to teach vocabulary at Genta English course?

\section{METHODOLOGY}

This research uses descriptive qualitative as research design. The qualitative research design is natural research that purpose conjugate phenomenon which happens and it is done by involving the various taught method. In this study the researcher made instrument to find problem. The research did observation, interview, and documentation. The observation was done during the class, it's from start until the end of class. The interview was conducted with the director, tutor and student. The researcher collected the documentation need in research.

Here, the research describes four aspects regarding the strategies used by English teacher to teach vocabulary at at Genta English Course. It was classified below: (1) teaching preparation of strategies used by English teacher to teach Vocabulary at Genta English Course, (2) implementation of strategies used by English teacher to teach vocabulary at Genta English Course, (3) student's response after learning vocabulary, (4) evaluation of strategies used by English teacher to teach vocabulary.

\section{RESULT OF STUDY}

After all results of instruments are collected, it shows that there are several things can describe the result of this study.

1. The teacher's preparation of strategies used by English teacher to teach vocabulary at Genta English Course (curriculum, syllabus, lesson plan, method and media). Based on research findings the discussion was about in teaching vocabulary at Genta English Course. It contained the curriculum and syllabus, media, method and source. The discussion as followed:

a. Curriculum. Based on findings that Genta English Course did not have a curriculum as their teaching guide as like in formal education because they 
thought that curriculum was not important for the Non formal education and it will be disturb the teaching process. They are focus on how to make the student understood the lesson easily and happy.

b. Syllabus. Based on the finding Genta English have own standard syllabus. It only for standars. Genta English course was focus on how to make the student understand which was helped by tutor in there. For Genta English course syllabus is not need because it is Non formal education.

c. Lesson Plan. Based on the finding Genta English have own standard lesson plan. Genta English course was focus on how to make the student understand which was helped by tutor in there. For Genta English course lesson plan is not need because it is Non formal education.

d. Method. Based on the findings Genta English course used discussing in their teaching. The teacher gave some topics that related with module. In the next day the topics was discuss in class one by one with repeated word itself to make student clear and understand. It could be 2 until 3 time to make the student memorize correctly. Sometimes teacher asked the student one by one.

e. Media. Based on the findings Genta English Course in teaching vocabulary used media instead of white-board, marker, dictionary and oxford. The white-board for making the student wrote all about the vocabulary they got. The teacher wrote a word that the student did not understand the meaning. Dictionary was for looking for meaning and oxford for looking for how to read the vocabulary correctly.

2. The Implementation of Strategies used by English teacher to Teach Vocabulary at Genta English course. Based on the finding, it found the teacher implementation of strategies used by English teacher to teach vocabulary at Genta English course is including 3 points, they are method, media and sources.

3. The Student Response after Learning Vocabulary. Based on the findings, the student response after learning vocabulary:

a. The students were very enthusiastic to follow the lesson. It can be seen from how their bravely came forward to mention vocabulary that the teacher gave.

b. The students were very enthusiastic to follow the lesson but a little bored when the teacher asked them to memorize the vocabulary words.

4. The evaluation of strategies used by English teacher to teach vocabulary. Based on the findings, the evaluation of strategies used by English teacher to teach vocabulary is they tend to adjust to the condition of their students ability. Gave the students a correct and understandable explanation, gave additional assignments (homework), assessed their students vocabulary every meeting or at least once in week. Tutor often ask one by one of the students to come forward and practice their memorizing that related with the topic, explain something or mention some vocabulary what they have been got. The teacher 
always give evaluation about the material that has been practice, remind the student for what they will do in the following meeting, giving some motivations.

\section{CONCLUSION}

Based on the research finding there are some conclusion, they are:

1. The teacher preparation in teaching vocabulary was fair because the course does not have curriculum but they have a standard curriculum itself, and for syllabus, lesson plan, method and media, this institution have it but it will be change once a week for reveal.

2. The implementation of strategies used by English teacher to teach vocabulary was good it can be seen in the pre teaching has been accordance with standard of learning process, whilst teaching has been good, the teacher can implied the strategies correctly, and in the post teaching has been good, the teacher held formative evaluation.

3. Student response after learning vocabulary is very enthusiastic, 10 students from 15 student follow the lesson even they sometimes they feel bored because they should memorize the lesson but day by day they can enjoy it and feel challenged

4. Evaluation of teacher strategies to teach vocabulary was good because the student ability and score increase long by long. They got certificate if they can passed the final examination.

\section{REFERENCES}

Alkahtani. (2015). Teaching of English as Foreign Languages. Surakarta: Muhammadiyah University Press.

Amvella. (2002). Teaching Vocabulary Method. Cambridge: Cambridge

University Press. Azwar, Saifuddin. Dr. MA. (2011). MetodePenelitian. Yogyakarta: PustakaPelajar.

Bakti. (2017). Vocabulary Learning Strategis Used by Junior High School Student, Indonesian Journal of English Languages Studies. 3, 2.

Brown. H. Douglas. (2001). Principles of Language Learning ang Teaching. New Jersey: Prentice Hall.

Cameron, Lynne. (2001). Teaching Languages to Young Learners. New York: Cambridge University Press.

Cook. (2008). Strategy in Teaching Vocabulary. UK: Cambridge University Press.

D, Nurina. (2009). The Total Physical Response (TPR). UNS

Harmer, J. (2001). The practice of English language teaching. (3rd.). Cambridge: Longman.

Harvey, F. S., Richard, W. S., \& Matthew J. P. (2007). The strategic teacher: Selecting the right research-based strategy for every lesson: New York.

Hornby, A. S. (2006). Oxford Advanced Learners Dictionary of Current English. Oxford: Oxford University Press. 
Pikulski and Templeton. (2004). Type of Vocabulary. Longman Press.

Schmitt. (2000). Teaching Oriented Perspektive. California: Nisage Publication AsiaPacific. Pte Ltd.

Sugiyono. (2007). Metode Penelitian Pendidikan: Penelitian Kuantitatif, Kualitatif, dan R\&D. Bandung. Alfabeta.

Suharsimi, Arikunto. (2007) Penelitian Tindakan Kelas. Jakarta: Rineka Cipta.

Suyanto, K. E. (2007). English for Young Learners. Bumi Aksara: Jakarta.

Thornbury, S. (2001). How to Teach Vocabulary. Longman Press.

Wallace, Michael, J. (1998). Action Research for Language Teachers. Cambridge: Cambridge University Press. 